\title{
Variables Affecting the Book Value of Manufacturing Companies: The Case of Indonesia
}

\author{
Submitted 5/12/18, 1st revision 13/1/19, accepted 9/2/19
}

Widi Hidayat ${ }^{1}$, Amalia Rizki $^{2}$, Riska Nur R. ${ }^{3}$, Tri Ratnawati ${ }^{4}$, T. Evan Tandiyono ${ }^{5}$

\begin{abstract}
:
The research objective is to examine variables that can be used as crucial determinannts for the book value of manufacturing companies in Indonesia.

The distinguishing variables are investment decisions, size of company, risk management issues, profitability and cash flow. The research design uses quantitative descriptive methodology with a sample of 25 manufacturing companies listed in the Indonesian Stock Exchange, for 4 consecutive years so that the number of units of analysis becomes 100 for the time series cross-sectional method used (pulling data).

The analysis technique uses discriminant statistics that are processed with SPSS. The cash flow variable has a value of Wilks 'Lambda of 0.446 and a significance level of 0.000 which means that the cash flow variable tends to have different effect in different groups of companies.
\end{abstract}

Keywords: Price Book Value, Cash Flow, Manufacturing Companies.

\footnotetext{
${ }^{1}$ Universitas Airlangga, Surabaya, Indonesia, h.widi.h@gmail.com

${ }^{2}$ Universitas Airlangga, Surabaya, Indonesia

${ }^{3}$ Universitas Airlangga, Surabaya, Indonesia

${ }^{4}$ Universitas 17 Agustus 1945, Surabaya, Indonesia, tri.wdhidayat@yahoo.com

${ }^{5}$ Universitas 17 Agustus 1945, Surabaya, Indonesia, tan_evan85@yahoo.co.id
} 


\section{Introduction}

Capital markets are formed to carry out economic and financial functions in the country's economic system. The capital market is a complement in the financial sector to two other institutions, namely banks and financial institutions that provide services to connect funds from parties that have excess funds (investors) to parties in the productive sector who need funds. Investors will expect profits from investments that have been made and have rights in the ownership of the company without having to be directly involved in it, otherwise the company obtains alternative sources of funding without waiting for the availability of funds from the results of the company's operations.

Investment, especially in securities, makes investors to think rationally in the face of trading in the capital market. In general, the capital market is defined as an organized financial system, including commercial banks and all intermediary institutions in the financial sector, as well as all outstanding securities. In short, the capital market is a market (a place in the form of a building) which is prepared to trade stocks, bonds, and other types of securities using the services of securities brokers (Sunariyah, 2004). Before investing on stock transactions, investors need to equip themselves by understanding several analytical methods that are easily applied in accordance with the personal and convenience of investors, so that these risks can be prevented. In fact, it is possible that assets or funds owned have the potential to grow rapidly.

For investors who conduct company analysis, any accounting information issued by the company is sufficient to describe the development of the company's condition up to that point and what it has achieved. With an analysis of accounting information, investors can find out the comparison between the intrinsic value of the company's shares compared to the market price of the company's shares, and on the basis of these comparisons, investors will be able to make a decision whether to buy or sell the shares concerned for profit. One of the fundamental indicators of a stock is price per book value (PBV) which is widely used by investors and analysts to find out the fair value of shares. This indicator is obtained by dividing the share price in the stock market with the value of the book value of the stock. Shares that have a large PBV ratio can be said to have a high valuation (overvalued) while stocks that have PBV below 1 have a low valuation or they are undervalued.

\section{Literature Review}

\subsection{PBV (Price Book Value)}

Market ratio is an indicator to show important company information in measuring stock market price performance (Ang, 1997). The market ratio used is Price to Book Value which is used to measure the performance of stock prices against the value of the book. Book value is the value of equity divided by the number of shares 
available. It can be said that book value is the value of equity per share. Equity itself is obtained from the difference in the number of assets minus liabilities. In theory this is the value that will be obtained by the shareholder if the company is liquidated. So the value of the book value is very meaningful to see the returns on investment. For companies that are running well, generally this ratio reaches above one, which indicates that the stock market value is greater than the book value. If PBV increases then the PER value will increase (Ghesa Ramadhani, 2014; Hapsoro and Suryanto 2017).

We often find in the market that there are stocks that have a large PBV. This is because the application of an accounting system that does not provide value to intangible assets such as brands and prospects of a company. Therefore there are many companies that have PBVs far above 1 and can reach tens, that is reasonable when viewed from the company's ability to generate profits and well-known brands. On the other hand PBV below 1.0 can indicate that the company has a bleak outlook. This is the reason why there are differences between market value and equity value itself. PBV value will be high if the company's performance is good. This means that the better the company's performance, the PBV ratio will increase from year to year. High demand will cause stock prices to increase. This is consistent with signaling theory because it can provide positive information that attracts investors.

Not all companies that have PBVs below 1.0 are undervalued companies. It could be that these stocks do have a low PBV because the company loses so that in later years the book value will decrease. If there is an event like this, it is only natural that the company has a PBV that is low and does not indicate that the company is undervalued. Conversely, stocks that have a high PBV cannot also indicate that the stock is overvalued because the company may have good prospects and performance and a well-known brand. So it makes the stock price to have a premium valuation compared to stocks that have a lower PBV but with a lower future prospect as well.

\subsection{Prosperity of Shareholders}

The advantages of maximizing company value or shareholder prosperity are conceptually clear as a guideline in decision making that considers risk factors. In achieving these objectives financial management must be able to balance the interests of owners, creditors and other parties related to the company. Adopting the prosperity of shareholders or company owners does not deny the existence of social objectives or social obligations. Social responsibility is an important aspect of company goals, meaning:

1. The success of maximizing the value of the company will make a meaningful contribution to the overall social environment.

2. The influence (impact) of the external environment such as pollution, work safety, product safety must also be taken into account.

3. Sensitivity to external factors is one of the important conditions so that the company can maintain the survival of the company. 
4. Companies must be able to maximize the prosperity of shareholders in legal and social constraints and are responsible for environmental changes.

Maximizing shareholder prosperity is a more appropriate goal as a guide to financial management decisions. Maximizing prosperity means forcing the present value of all future profits to be received by the owner of the company. The advantage of maximizing shareholder prosperity is that conceptually is clearly a guideline in decision making, which considers risk factors. Management must be able to balance the interests of owners, creditors and other parties related to the company. Value maximization emphasizes cash flow rather than just net income in an accounting sense.

\subsection{Capital Gains}

Capital gain is a profit obtained by shareholders, when selling shares or is the difference between the selling price and the purchase price. The difference between a higher selling price and a lower purchase price results in financial benefits for the investor. In contrast, capital losses occur if the securities or property are sold at a price lower than the purchase price. Capital gains can refer to "investment income" that arises in relation to investments made in the property sector, financial assets (securities) such as stocks or bonds and derivative products and intangible assets such as "goodwill" according to investment guidelines. There is a policy about the time of potential gain and potential loss that must be realized as well as differences in costs and expenses in certain accounting.

The capital loss policy cannot be more than 10 percent. For example, the EFG stock price drops by 10 percent, investors must sell shares or realize their losses so that they will not lose more because the shares can go down again. The same is true for realizing potential gains. If the policy states that the potential gain must be realized at 30 percent, then when the stock rises by 30 percent, the stock must be sold first because the stock can actually decrease in price. There are other policies that require investors to buy shares again at a higher price so that investors must pay close attention to policy applied. Such cases are common when investors buy shares at a higher price even though they have just sold them at a lower price. The cost accounting function has a role in stock transactions so it must be considered continiously.

\subsection{Dividends}

Dividend is a pro rata distribution of profits by the company to its shareholders. Prospective buyers and sellers are very interested in the company's dividend policies and practices. Dividend policy consist of 4 types, namely:

1. Cash Dividends;

2. Property Dividends;

3. Scrip dividendss (promissory notes to pay cash); 
4. Share Dividends.

\subsubsection{Cash Dividends}

Cash dividend is the pro rata distribution of cash to shareholders. The majority of companies distribute dividends to shareholders in cash.

\subsubsection{Share Dividends}

Share dividend is the distribution of shares of the company concerned pro rata to its shareholders. If cash dividends are paid in cash, stock dividends are paid in shares. In addition to dividend distribution in the form of securities, the most common alternative is dividends in the form of shares - if the company lacks liquidity (cash). Dividend distribution of types of stock is usually given equally to all shareholders. The distribution of share dividends actually does not cause the company's wealth to decrease. The net asset value of the company remains as before the dividends' distribution. Likewise with the composition of ownership. Transactions are carried out by capitalizing retained earnings. This means that retained earnings (in part or in whole) are transferred to the capital account. So, paid up capital increases, while retained earnings are reduced or exhausted.

\subsection{Stock Price to Book Value}

One ratio that is widely used in making investment decisions is the ratio of stock prices to company book value (price to book value ratio). The book value of a company is the value of the company's assets divided by the number of shares issued by the company. In other words, the book value of shares is the fair value of the issuer's shares, which reflects the fundamentals. While stock prices can be influenced by many factors and various sentiments. In addition to fundamentals, technical factors, supply demand, sentiment factors in the industry related to the company and other factors are also influenced. Then the term stock prices appear either overvalued or undervalued. The stock price is said to be overvalued if the share price exceeds the company's book value while undervalued if the stock price is below the company's book value (Suharno and Dini, 2018).

The stock price that is below the book value of the company has great potential to rise, because it does not reflect actual performance. While the stock price that is too high above the price of the book is a bit cautious because the possibility of the price will be corrected according to the book value. But it could be that overvalued prices are due to the company's long-term prospects that are valued by investors with the support of the analyst's research. Stock prices on the stock exchange always reflect the company's estimated performance or book value in the future. Because basically people who buy shares are buying the future investing in the long term. The price to book value ratio (PBV) indicator is used to show how far a company is able to create firm value relative to the amount of capital invested, the higher the ratio the more successful the company creates value for shareholders. By knowing the PBV ratio, investors can identify which shares are reasonable, undervalued or overvalued. 


\section{Methodology}

The research design uses quantitative descriptive analysis with a sample of 25 manufacturing companies listed in the Indonesian Stock Exchange, for 4 consecutive years so that the number of units of analysis is 100 using time series cross-sectional methodology (pulling data). The analysis technique uses discriminant statistics that are processed with SPSS. Distinguishing variables are investment decisions, firm size, risk management, profitability and cash flow.

\section{Results and Discussion}

Test of Equity of group means is the result of analysis to test the similarity of the average variable. This test uses Wilks' Lambda and significance values. From Table 1 below, it can be seen that Wilks' Lambda and the significance level for each variable are as follows:

Table 1. Test of Equity of Group Means

\begin{tabular}{|l|r|r|r|r|r|}
\hline & $\begin{array}{c}\text { Wilks’ } \\
\text { Lambda }\end{array}$ & \multicolumn{1}{c|}{$\mathrm{f}$} & df1 & Df2 & \multicolumn{1}{c|}{ Sig. } \\
\hline Invesment_Decision & .748 & 1.210 & 15 & 54 & .293 \\
Firm Size & .870 & .540 & 15 & 54 & .906 \\
Risk_Management & .914 & .340 & 15 & 54 & .988 \\
Profitabilitas & .559 & 2.845 & 15 & 54 & .002 \\
Cash_Flow & .446 & 4.480 & 15 & 54 & .000 \\
\hline
\end{tabular}

a. Investment decision variable has a Wilks' Lambda value of 0.748 and significance level 0.293, which means that investment decision variable tends to have no differences in groups because it has a value of Wilks' Lambda not close to 0 and on hypothesis testing no differences in groups because the significance level is above 0.05 .

b. Firm size variable has a Wilks' Lambda value of 0.870 and significance level 0.906 , which means that the firm's size variable tends to have no differences in groups because it has a value of Wilks' Lambda not close to 0 , and on hypothesis testing no differences in groups because the significance level is above 0.05 .

c. The risk management variable has a Wilks' Lambda value of 0.914 and significance level 0.988, which means that the risk management variable tends to have no differences in groups because it has a value of Wilks' Lambda not close to 0 and on hypothesis testing no differences in groups because the significance level is above 0.05 .

d. The profitability variable has a Wilks' Lambda value of 0.559 and significance level 0.002 , which means that the profitability variable tends to have no differences in groups because it has a value of Wilks' Lambda close to 0 , and on hypothesis testing differences in groups because the significance level is below 0.05 . 
e. The cash flow variable has a Wilks' Lambda value of 0.446 and significance level 0.000 , which means that the cash flow variable tends to have no differences in groups because it has the value of Wilks' Lambda not close to 0 , and on hypothesis testing differences in groups because the significance level is below 0.05 .

Table 2. Variables Entered/Removed ${ }^{a, b, c, d}$

\begin{tabular}{|c|l|r|r|r|r|r|r|r|c|}
\hline & & \multicolumn{9}{|c|}{ Wilks' Lambda } \\
\cline { 3 - 8 } & & & & & & \multicolumn{4}{|c|}{ Exact F } \\
\cline { 5 - 10 } $\begin{array}{c}\text { Ste } \\
\text { p }\end{array}$ & \multicolumn{1}{|c|}{ Entered } & Statistic & df1 & df2 & df3 & Statistic & df1 & df2 & Sig. \\
\hline 1 & $\begin{array}{l}\text { CASH_FLO } \\
\text { W }\end{array}$ & .446 & 1 & 15 & 54.00 & 4.480 & 15 & 54.000 & .000 \\
\hline
\end{tabular}

From Table 2 above, based on the discriminant test for the cash flow variable, the stepwise regression shows that there is a variable that can distinguish the PBV of manufacturing companies, namely the cash flow variable, having a significant effect on the dependent variable.

Table 3 shows the variables that remain in the model, namely the cash flow variable with the tolerance value and the $\mathrm{F}$ value to remove.

Table 3. Variables in the Analysis

\begin{tabular}{|ll|r|r|}
\hline Step & Tolerance & \multicolumn{2}{|c|}{ F to Remove } \\
\hline 1 & CASH_FLOW & 1.000 & 4.480 \\
\hline
\end{tabular}

Table 4 presents the Eigenvalues with the value of the Canonical Correlation which shows that the relationship between discriminant values in groups is very high, 0.745 , close to 1 .

Table 4. Eigenvalues

\begin{tabular}{|c|r|r|r|r|}
\hline Function & Eigenvalue & \% of variance & Cumulative \% & $\begin{array}{c}\text { Canonical } \\
\text { Correlation }\end{array}$ \\
\hline 1 & $1.244^{\mathrm{a}}$ & 100.0 & 100.0 & .745 \\
\hline
\end{tabular}

\section{Summary}

Investment decisions are thought to be able to distinguish price book value, because investment decisions taken by manufacturing companies should produce a favorable return of investment, which appreciates the increase in stock prices. Thus it will increase the price book value. Based on discriminant statistical tests it has been proven that investment decisions cannot distinguish significantly the price book value, thus a strategy is needed to increase the return of investment in order to provide a positive signal for the increase of the price book value. 
The variable size of the company or firm size is able to distinguish price book value in manufacturing companies, this is because the size of the company, as measured by total assets, is a reflection of the company's value and the increasing company value reflects the positive prosperity of shareholders. Shareholders' prosperity is measured by capital gains and dividends, while capital gains are stock returns obtained from an increase in stock prices at the time of purchase and at the time of sale. If the stock price at the time of sale is greater than the stock price at the time of purchase, then the shareholders will get capital gains. Thus, the increase in stock prices becomes very important because of the prosperity of the shareholders. Hypothesis testing results that are processed with discriminant statistics indicate that firm size cannot determine price book value, that means that it is required to exist a strategy to further increase the firm size, especially on assets and sales. This strategy must lead to a higher level of production in the company under question.

Risk management is very important for manufacturing companies considering that manufacturing companies process raw materials into finished goods which have very much labor and also depend on the production equipment and technology used, while also having foreign competitors in the form of goods, imported goods that have been made at a cheaper price. The reason why the risk management can determine the price book value for manufacturing companies is because if the risk management of a company is high, it will affect the shareholders' security, which is called stock return, which among others is the increase in stock prices, so the higher the risk management the lower the price book value. The results of hypothesis testing with discriminant statistics show that there is insufficient evidence of risk management in determining the price book value. The strategy that must be done by manufacturing companies is to mitigate risk as low as possible so that it can have an effect on increasing its price book valuation. The next strategy that must be done is to improve financial performance, especially on financial performance related to risk management, for example the ratio of sales growth, profit growth and liquidity ratios which signal a rise or decrease in price book value.

Profitability is hypothesized to be able to determine price book value because profitability is the result of net profits produced by manufacturing companies during a period that shows the ability of manufacturing companies to generate profitability. High profitability is a signal for the prosperity of the shareholders, because the stock returns in the form of dividends, the payment depends on the size of the profitability produced. The results of hypothesis testing with discriminant statistics show that it turns out that profitability is not proven to be able to distinguish price book value, this is because profitability produced by manufacturing companies is relatively small. The strategy that must be carried out is to increase sales or the revenues of manufacturing companies and make efficiency on operating costs which include cost of production and other operating costs.

Cash flow is thought to be able to differentiate price book value because cash flows from the activities of all manufacturing companies are centered on cash flow 
activities. Based on the financial accounting standard board (FASB) and accounting standards, cash flows include cash flows from operating activities, cash flows from investment activities and cash flows from financing activities. Thus the effectiveness of cash flow will be able to appreciate the increase in price book value. The financial strategy that must be carried out is to keep securing cash flow from operational activities, investment activities and funding activities so that the manufacturing company can distinguish price book value, the healthier the cash flow of manufacturing companies, the better the price book valuation, and vice versa.

\section{Conclusions}

The results of the study to test investment decisions, firm size, risk management, profitability and cash flow are as follows:

The cash flow variable has a value of Wilks' Lambda 0.446 and significance level 0.000 which means that the cash flow variable tends to have differences in groups because the value is not close to 0 , but hypothesis testing shows differences in groups because the significance level is below 0.05. All other variables considered in this research have the opposite results.

\section{References:}

Cahyaningrum, Yustiana Wahyu. 2017. Effect of Earning Per Share, Price to Book Value, Return on Assets, and Return on Equity Against the Price of Financial Sector Stocks. Economia Journal, Volume 13, Number 2.

Hapsoro, D., Suryanto, T. 2017. Consequences of Going Concern Opinion for Financial Reports of Business Firms and Capital Markets with Auditor Reputation as a Moderation Variable: An Experimental Study. European Research Studies Journal, 20(3), 3-20.

Herlambang, G. 2016. Understanding Price to Book Value. Jakarta.

Meythi, 2012. Effect of Price Earning Ratio and Price to Book Value on LQ 45 Index Stock Returns (Period 2007-2009). Journal of Accounting Vol. 4, No. 1, 1-21.

Suharno, P., Dini, I. 2018. The Influence of Work Stress, Working Cost, Compensation and Work Discipline on Employee' Productivity. International Journal of Economics and Business Administration, 6(4), 62-75.

Sujana, Edy, Najmiyah. 2014. Effect of Price To Book Value (PBV), Price Earning Ratio (PER) and Debt To Equity Ratio (DER) Against Stock Returns on Real Estate and Property Industries Listed on the Indonesia Stock Exchange for the 2009-2013 Period. E-Journal 1 Ak University of Education Ganesha.

Utomo, W. 2016. Effect of Leverage (DER), Price Book Value (PBV), Company Size (size), Return on Equity (ROE), Dividend Payout Ratio (DPR) and Liquidity (CR) Against Price Earning Ratio (PER) in Manufacturing Companies That Listing on the Indonesia Stock Exchange for 2009-2014. Journal of Accounting, Volume 2. 